\section{Research Article}

(C) 2022 Munir et al. This is an open access article licensed under the Creative Commons Attribution-NonCommercial 4.o International License

(https://creativecommons.org/licenses/by-nc/4.o/)

\title{
State of The Art Para-Diplomacy: A Systematic Mapping Studies and a Bibliometric Analysis VOS Viewer in Scopus Database
}

\author{
Fitrisia Munir ${ }^{1 *}$ \\ Yanyan Mochamad Yani \\ Yusnarida Eka Nizmi ${ }^{3}$ \\ Cifebrima Suyastri ${ }^{4}$ \\ ${ }^{1}$ Lecturer in Department of International Relations, \\ Universitas Islam Riau, Jl. Kaharuddin Nst No.113, Simpang Tiga, Kec. Bukit Raya, \\ Kota Pekanbaru, Riau 28284, Indonesia \\ ${ }^{2}$ Professor in Department of International Relations, Universitas Padjadjaran, \\ Jl. Raya Bandung Sumedang KM.21, Hegarmanah, Jatinangor, \\ Kabupaten Sumedang, Jawa Barat 45363, Indonesia \\ ${ }^{3}$ Senior Lecturer in Department of International Relations, Universitas Riau, \\ Kampus Bina Widya KM. 12,5, Simpang Baru, Kec. Tampan, \\ Kota Pekanbaru, Riau 28293, Indonesia \\ ${ }^{4}$ Lecturer in Department of International Relations, Universitas Islam Riau, \\ Jl. Kaharuddin Nst No.113, Simpang Tiga, Kec. Bukit Raya, \\ Kota Pekanbaru, Riau 28284, Indonesia \\ ${ }^{*}$ Corresponding Author
}

DOI: https://doi.org/10.36941/ajis-2022-004o

\section{Abstract}

Purpose: This article examines state of the art or the most recent achievements of Para-diplomacy research in international relations. For this reason, the systematic mapping studies (SMS) and the bibliometric analysis VOS Viewer carried out stared at articles from 1984 to 2020, as comparison bibliographic articles from countries in the Scopus database. Methods: Preliminary analysis was conducted from systematic mapping studies followed by bibliometrics of publication content in the Scopus database. A total of 175 documents met the criteria for inclusion, starting in 1984, and the dominant author from Europe in journal Scopus Q1 and other well-known international journals. The data from the search results are then descriptively analyzed based on the journal-title, author, co-author, year of publication country, affiliation, keywords, journal /publication name. Results: Researchers from American countries were more productive than Europe and fewer in Asia from 1984 to 2021. As far as paper European document quality is concerned, American governments have significantly more author quality than Asian countries. Conclusion: Although fewer Para-diplomacy articles are published by researchers from Asian countries than Europe and America, this is a challenge for Asian researchers. The increase in the number of publications over the last ten years has shown that the turmoil of sub-state actors in Asian countries has begun to consider implementing regional Para-diplomacy. This is due to a strong push for regional progress to open wide-ranging cooperation, either directly or indirectly, with other countries/regions to strengthen the objectives of state sovereignty.

Keyword: Para-diplomacy, Systematic Mapping Studies, Bibliometric Analysis VOS Viewer 


\section{Introduction}

Para-diplomacy is an instrument for promoting regional identity. It can be explained that the emergence of regions as transnational actor results from the reinforcement of sub-state identity. Rohan Butler coined the term Para-diplomacy in 1961 and was widely used early in the 1990s $(($ Kuznetsov, 2014));((Lequesne \& Paquin, 2017))). Para-diplomacy involves sub-state actors such as states, provinces, regions, local governments, and cities in their international activities. The concept of Para-diplomacy, defined as the fundamental aspect of globalization and regionalization and in which sub-state actors have an increasing influence in the political world, was introduced and created by Duchacek $(1984,1990)$ and Soldatos (1990) in the academic debate. Duchacek (1984) describes the multi-level Para-diplomacy approach in global relations as no new issue ((Duchacek, 1984)). The institutional approach is confirmed because its impact on the structure and activities of the international sub-states has changed in the world (Keating, 1999). The research of Para-diplomacy in many countries has dramatically evolved in line with the success of globalization and modernization. So far, Para-diplomacy studies have been concentrated mainly in Europe and North America. Paradiplomacy appears in federal and non-federal states as campaigns involving sub-state players in complete foreign activities (Cornago, 1999).

Countries in Europe and America are the primary driving force behind this idea, in comparison to countries in Asia directly affected and involved in international affairs. In light of the Québec independence campaign and the new federalism of Richard Nixon, interest among sub-state players in the international system was early favored(Liu \& Song, 2020). In the literature study conducted by researchers, a significant increase occurred in the number of Para-diplomacy research articles published in the Scopus database over the past ten years. This research is increasingly important because it involves sub-state actors to realize regional or state interests as part of its foreign policy objectives. The capacity objectives of the sub-state actors are less anarchist and destructive but more pragmatic and skilled, through well as more organized and coordinated Para-diplomacy activities. It shows that economic globalization, federalism, and decentralization have led to an increase in the Para-diplomacy activities of sub-state units.

\section{Review of Literature and Theoretical Framework}

This article adds to the literature to enhance the existing theoretical framework to better reflect the most important dimensions of international actors and broaden the geographical scope of the study of Para-diplomacy. This is one of the first academic attempts to carry out a systematic review of the existing literature on Para-diplomacy concept and Para-diplomacy dimensions. This research identified countries with few published articles on para- diplomacy, such as Asia, with regions or countries adjacent to developed countries and directly involved in international affairs. Several theoretical and empirical studies published since the 1970s have focused on local government, as opposed to non-central government actors such as sub-ministerial sub-units (Keohane \& Nye, 1974), a legislature(Mansfield \& Milner, 1999), and bureaucracy(Slaughter, 2004). This study has tried to explain the external activities of local governments and literature on Para-diplomacy provides an alternative lens to understand this phenomenon. There are distinct phases to researching the role of local government as an international player and this phase focuses on the beginning of the study of Para-diplomacy in the 1970s, with a focus on North America, stimulated by the Nixon administration's "new federalism" policies in the United States and the independence movement in Quebec.

\section{Methods}

Declaration of ethics: Several systematic literature reviews and mapping studies (SMS) on paradiplomacy have been published, providing a comprehensive understanding of the role of sub-state 
actors(Barlow \& Craske, 2015). However, there is currently no SMS that can provide a systematic understanding of the complexities of para-diplomacy and its dimension(Babar et al., 2017). In this study, different systematic reviews were investigated in order to collect knowledge generated across various sub-domains of para-diplomacy. This study highlights the existing SMS's objectives and subobjectives, as well as information on para-diplomacy issues from various perspectives.

No approval or informed consent from the Institutional Review Board was required since the literature study was conducted. The study was designed as a systematic mapping study and bibliometric analysis of a specific topic from a literature database(Purnomo, 2015). The SMS (Systematic Mapping Studies) is used to describe the investigation activities conducted in this study. SMS depicts high-level research and maps instead of examining detailed research questions (Petersen et al., 2008). In other words, SMS may be seen as a means to provide a summary of certain areas of research because it examines detailed information from the SMS-based research (Kitchenham et al., 2012). SMS in the social sciences have increased in recent years, involving challenges in various studies and used to describe the type of research activities carried out (Munir \& Purnomo, 2019).

While other sciences have used this method for a long time, it is essential in researching international relations. Moreover, it may contribute to further research in the social sciences. Based on this study, recommendations are made for scholars who can be an outstanding guide in their research of the phenomena of some Para-diplomacy. In comparison to previous research, researchers must improve the subject of Para-diplomacy and phenomena, especially developments in third world countries. This research utilizes the Scopus database, considering that Scopus is a reputable database of recent publications. The data is downloaded at https://www.scopus.com and manually evaluated using CSV. The VOS Viewer visualization is used to analyze Para-diplomacy co-occurrence with VOS Viewer version 1.6.15 and is downloaded at /vosviewer.com/.

\section{Step for Research SMS}

The search and analysis process needs to be as accurate as possible to improve the accuracy of SMS studies. The method of selecting data sources, implementing strategies to generate search used " Kstrings " ("Para-diplomacy ") and defining exclusion and inclusion criteria is therefore characterized in this section. This study took a Petersen et al. search process (2008). Every step has a systemic result, and the map is the result of mapping (systematic mapping). Figure 1 shows the whole SMS process under Petersen et al.'s (2008) instruction (Petersen et al., 2008). 


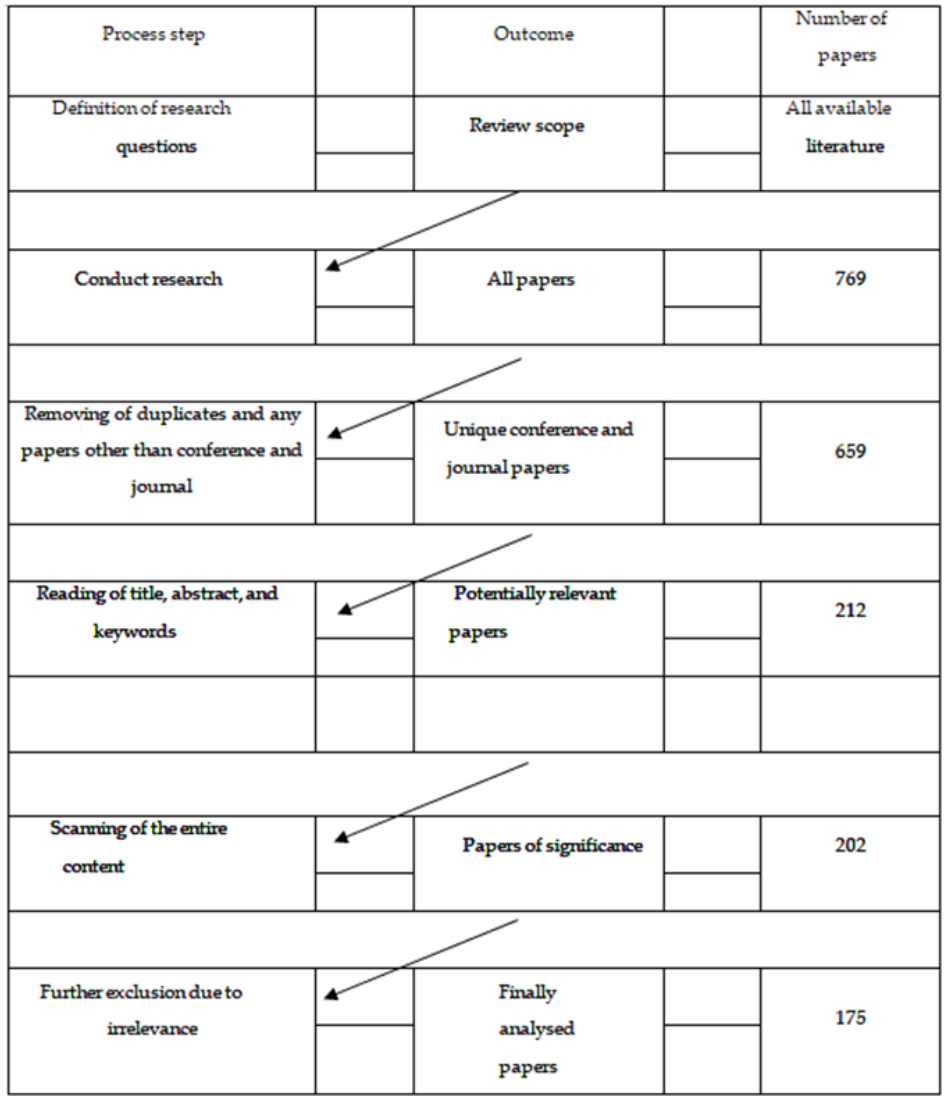

Figure 1: SMS Process

Source: Researcher 2020

\subsection{Inclusion and Exclusion Criteria}

Some of the mapping studies exclude irrelevant items and include relevant studies to determine the categories for exclusion and inclusion criteria of articles. In other words, it is only appropriate to check for relevant articles. The authors used the following criteria in this study to exclude and include articles (Table 1). Articles from peer-reviewed journals and conference articles examining the paradigm were the principal criteria for inclusion for articles considered as SMS data.

Discussion/opinion papers, which rely on secondary data, remain involved in the study of international relations and Para-diplomacy published in journals. In contrast, articles that do not include data or exclusion criteria are non-Para-diplomacy-related articles, editors, news, poster summaries and are not in English.

Table 1: Inclusions and Exclusions Criteria

\begin{tabular}{|l|l|}
\hline Inclusion & Exclusion \\
\hline 1.Research that focuses on Para-diplomacy & 1.Paper that does not discuss para- diplomacy \\
2. English Language & 2.Languages other than English \\
3.Only journal papers & 3.Thesis, book section, product description, presentation, job \\
\hline
\end{tabular}




\begin{tabular}{|l|l|}
\hline Inclusion & Exclusion \\
\hline 4.Paper that has passed peer reviewed & report, commercial literature, editorial note, gray literature. \\
& 4.Document not reviewed previously by peer \\
& 5.Research multiply \\
\hline
\end{tabular}

Source: Researchers Data, 2020

\subsection{Scheme of classification}

Researchers have developed a classification regime for analyzing and classifying articles that have been selected based on criteria (Kitchenham, 2007). We compile three aspects to organize the items collected. First, we classify articles in the first category according to methods of reference study. Second, the classification defines the type of research in the second category (paper type). In the third category, the keyword method described in Petersen et al. was identified in three categories (research focus) (2008).

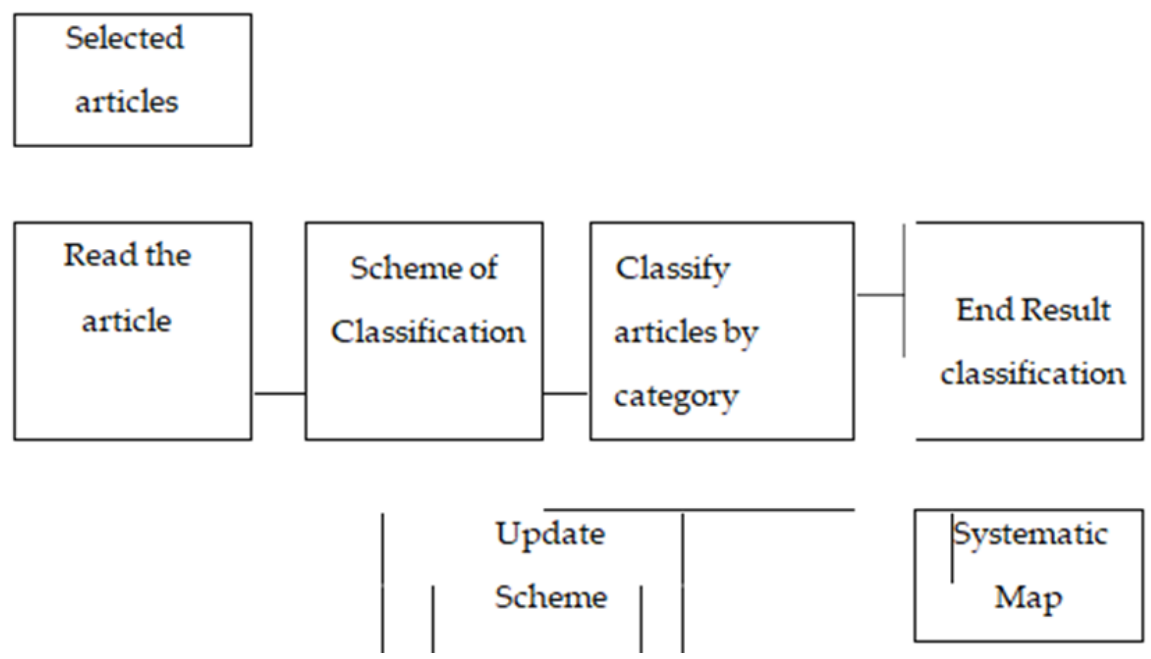

Figure 2: Classification Process

Source: Peterson et al (2008)

\section{Results}

\subsection{Systematic Mapping Studies}

Systematic Mapping Study (SMS) is a study that provides a comprehensive overview for academic researchers and practitioners this research as a preliminary study. The trend of Para-diplomacy in the study of international relations has historically been studied since 1984 and has experienced a very increasing development since non-Federal countries researched in the last decade. A steady increase in publication occurred from 2010 to 2020 , followed by the rise in articles released each year between 2017 and 2020. The number of themes has increased significantly to be registered as authors from several non-federal states in Asian countries, such as China, Hong Kong, and Indonesia. Figure 3 identifies the significant year of publication of the Para-diplomacy articles and the number of articles each year. 


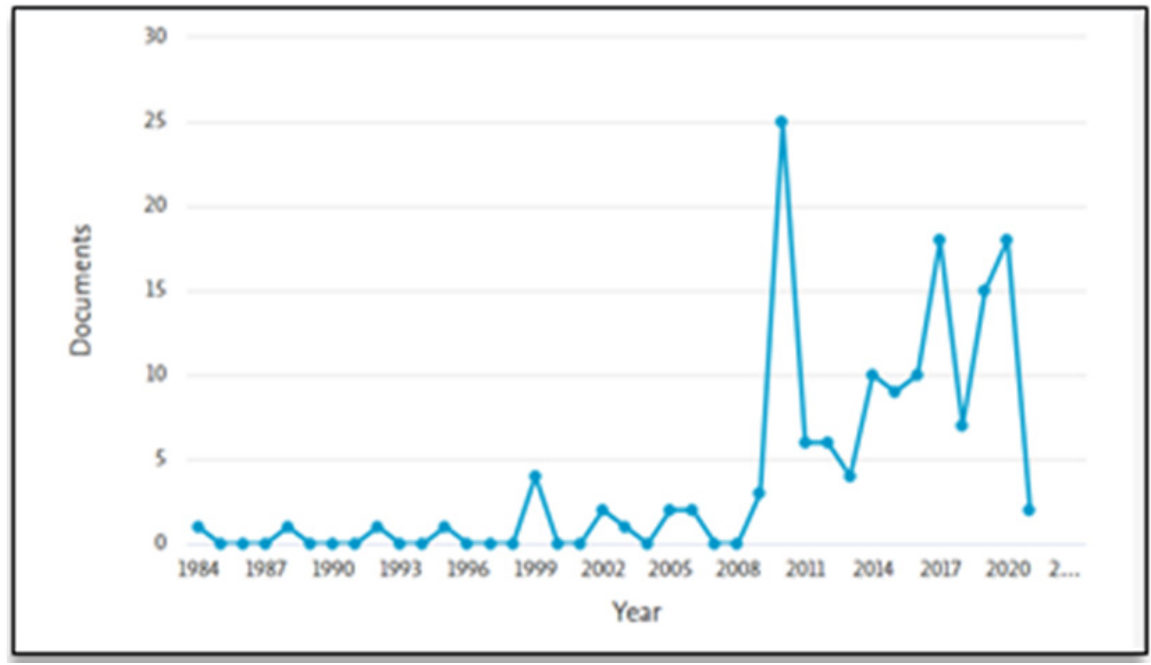

Figure 3: Potential data trends for Para-diplomacy publications in the Scopus database (on Year)

\begin{tabular}{|c|c|c|c|c|c|c|c|c|c|}
\hline \multicolumn{10}{|c|}{ Description: } \\
\hline \multicolumn{2}{|c|}{ Source } & \multicolumn{3}{|c|}{ http://www.scopus.com } & \multicolumn{2}{|c|}{ Search Area } & \multicolumn{3}{|c|}{ Title, Abstract, Keyword } \\
\hline \multicolumn{2}{|c|}{ Search Time } & \multicolumn{3}{|c|}{ January, 032020} & \multicolumn{2}{|c|}{ Result Search } & \multicolumn{3}{|c|}{175 Document } \\
\hline \multicolumn{2}{|c|}{ Search String } & \multicolumn{8}{|c|}{ TITLE-ABS-KEY (“Para-diplomacy”) } \\
\hline Year & Amount & Year & Amount & Year & Amount & Year & Amount & Year & Amount \\
\hline 1984 & 1 & 2002 & 2 & 2009 & 3 & 2014 & 12 & 2019 & 18 \\
\hline 1988 & 1 & 2003 & 3 & 2010 & 26 & 2015 & 10 & 2020 & 20 \\
\hline 1992 & 1 & 2005 & 3 & 2011 & 6 & 2016 & 15 & 2021 & 2 \\
\hline 1995 & 1 & 2006 & 3 & 2012 & 6 & 2017 & 19 & & \\
\hline 1999 & 4 & 2008 & 1 & 2013 & 4 & 2018 & 14 & & \\
\hline
\end{tabular}

Source: https://www.scopus.com

Researchers recognize that in the last 30 years, numerous papers on Para-diplomacy have been written and that several articles have begun contributing to this research from Asian countries (Tewari, 2017). The development of Para-diplomacy, which is increasingly contextual and consistent with progress in information technology, has led to several new Para-diplomacy variants(Aldecoa \& Keating, 2013). Detailed data analysis was carried out based on the year of publication, affiliation, authors and co-authors from abroad, journals, keywords, and multiple citations. Using the 'Paradiplomacy' option for the tracking of results and searches on the Scopus database for January 2021, 88 articles (America), 68 articles (Europe), 13 articles (Asia), 6 (Australia, Africa) in English were found, and the search was limited to articles between 1984 and 2021. The study of Para-diplomacy skyrocketed in 2010 ( 26 pieces) compared to the following year. This was due to the emergence of issues that mostly discussed the study of Para-diplomacy with the territories (Figure 4). 


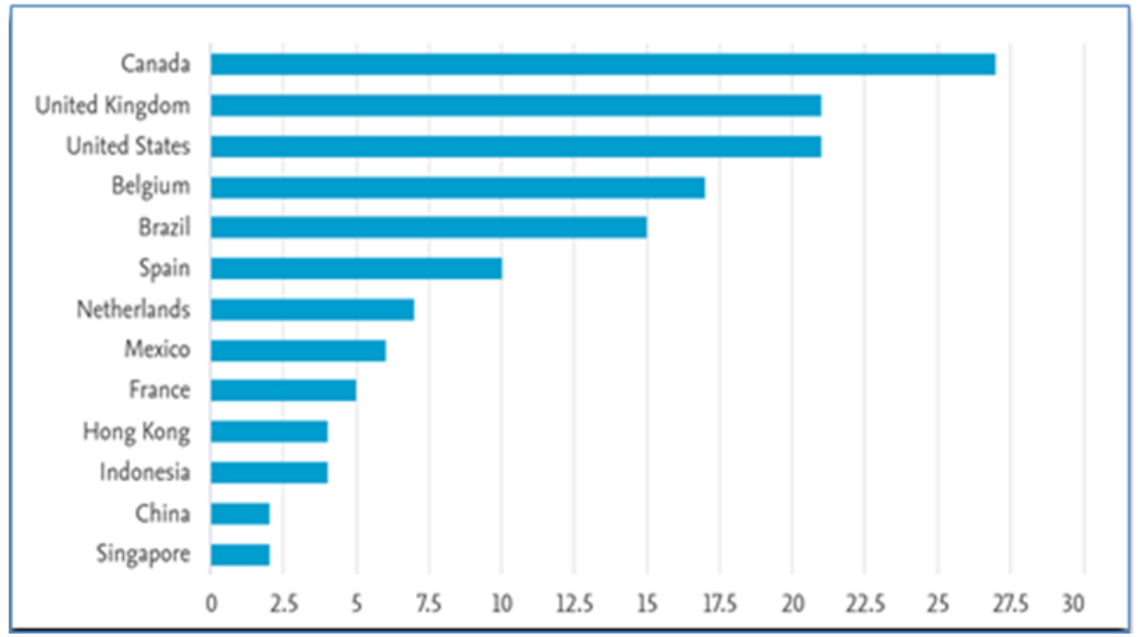

Figure 4: Trends in potential data from several countries for scientific publication of para- diplomacy in the Scopus database.

\begin{tabular}{|c|c|c|c|c|c|c|c|c|c|}
\hline \multicolumn{10}{|c|}{ Description: } \\
\hline \multirow{2}{*}{\multicolumn{2}{|c|}{ Source }} & \multicolumn{3}{|c|}{ http://www.scopus.com } & \multicolumn{2}{|c|}{ Search Area } & \multicolumn{3}{|c|}{ Title, Abstract, Keyword } \\
\hline & & \multicolumn{3}{|c|}{ January, 032021} & \multicolumn{2}{|c|}{ Result Search } & \multicolumn{3}{|l|}{175 Document } \\
\hline \multicolumn{2}{|c|}{\begin{tabular}{|l} 
Search Time \\
Search String
\end{tabular}} & TITLE-ABS-K & EY (“P & ra-diplomacy & & & & & \\
\hline \multicolumn{3}{|c|}{\begin{tabular}{|l|l|} 
Country & Amount Country \\
\end{tabular}} & \multicolumn{2}{|c|}{ Amount|Country } & \multirow{2}{*}{\begin{tabular}{|c|} 
Amount \\
5
\end{tabular}} & \multirow{2}{*}{\begin{tabular}{|l|} 
Country \\
Indonesia \\
\end{tabular}} & \multirow{2}{*}{$\begin{array}{l}\text { Amount } \\
\text { Germany }\end{array}$} & \multirow{2}{*}{\begin{tabular}{|l|} 
Country \\
Singapore
\end{tabular}} & \multirow{2}{*}{ Amount } \\
\hline Canada & 27 & Spain & 10 & Slovenia & & & & & \\
\hline UK & 21 & Netherland & 7 & $\begin{array}{l}\text { South } \\
\text { Africa }\end{array}$ & 5 & Australia & Greenland & Turkey & 2 \\
\hline US & 21 & Argentina & 6 & Chile & 4 & Austria & Iraq & Chez Republic & 1 \\
\hline Belgium & 17 & Mexico & 6 & Colombia & 4 & China & Norway & El Salvador & 1 \\
\hline Brazil & 15 & France & 5 & Hongkong & 4 & Finlandia & Rusia Federation & Ireland & 1 \\
\hline Israel & 1 & New Zealand & 1 & Uruguay & 1 & & & & \\
\hline Italy & 1 & Poland & 1 & Underfined & 9 & & & & \\
\hline Japan & 1 & Slovakia & 1 & & & & & & \\
\hline
\end{tabular}

\section{Source: https://www.scopus.com}

The United States has the highest collaborative productivity in publishing para- Diplomacy papers in international journals compared to Europe(Kaiser, 2003). Meanwhile, Asian-affiliated authors tend to publish journal papers in all Scopus quartiles. Countries in Asia dominate the unitary state compared to countries in America and Europe, and the emergence of research in the context of the unitary state can strengthen the concept of Para-diplomacy to participate in transnational networks in the signing of international agreements, thereby reducing the intervention and control of the central state(Lecours, 2002). Based on research, authors with affiliations from American and European countries are dominant in Scopus indexed Q1 journals named The Hague Journal of Diplomacy 15 Articles and Regional and Federal Studies 7 Articles, most of which publish articles in journals on the subject of diplomacy and international relations compared to other fields. Meanwhile, Asianaffiliated authors tend to publish papers in journals across all Scopus quartiles (Figure 5). 


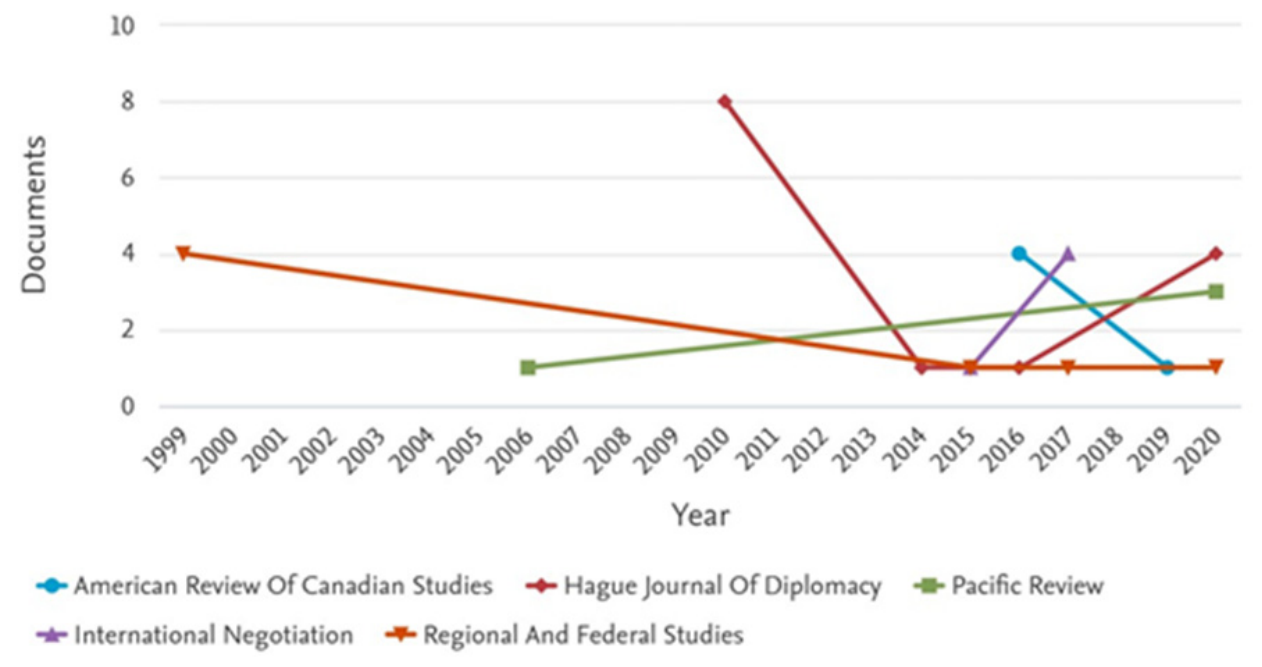

Figure 5: Trend for the publication of articles concerning Para-diplomacy in the Scopus database Source: https://www.scopus.com

\subsection{Bibliometrics Analysis (VoS Viewer)}

Bibliometrics is a research field that quantifies the publications of a journal, research institute, research field, country, or other entity. The terms bibliometrics, scientometrics, and informetrics refer to component fields concerned with the study of the dynamics of disciplines as reflected in their literature production(Wang et al., 2018). The areas of study range from charting changes in a scholarly field's output over time and across countries, to the library collection problem of maintaining control of the output, and to most researchers' low publication productivity. Bibliometrics can be used to assess the scientific impact of journals, authors, and research institutions, as well as to identify hot topics, newly emerging subjects, highly cited items, scientific collaboration patterns, interdisciplinary models, and so on (Wang et al., 2018).

In the VOS Viewer mapping visualization of 175 papers, articles are grouped by year of publication, foreign co-authors, corporate affiliations, journal names, keywords, groups, and quotation frequency are seen in figures 6,7 , and 8 . The analysis of network visualization shown in Figure 6 reveals that federal countries (America and Europe) still control the five main sub-themes of Para-diplomacy science rather than non-Federal/Unitary countries (Asia). 


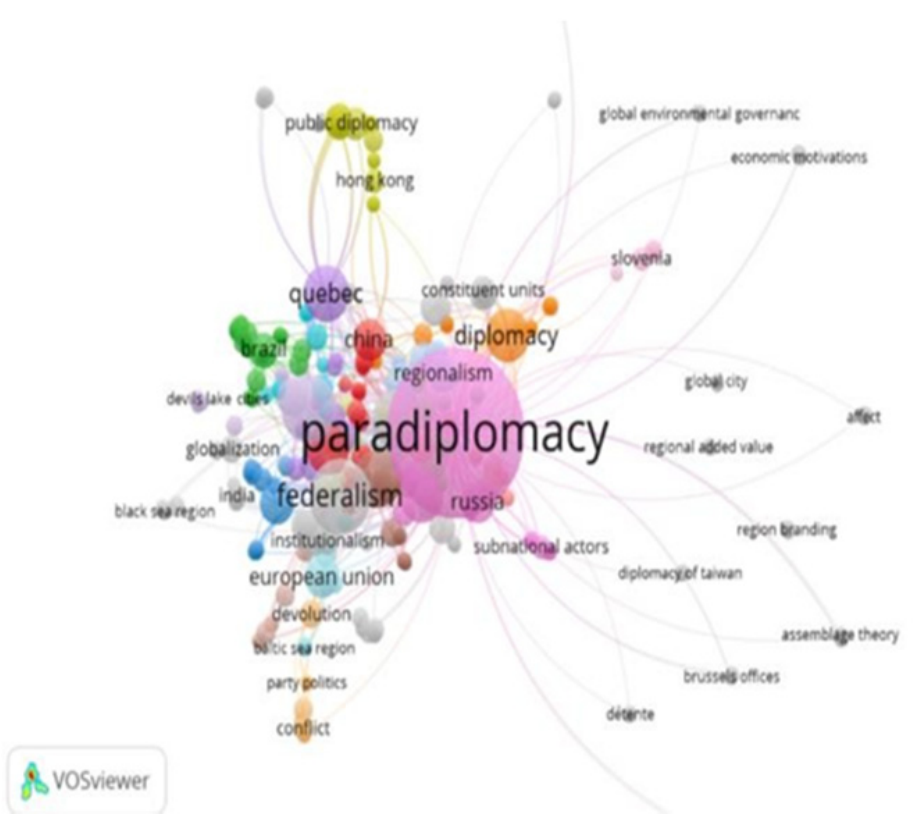

Figure 6: Network Visualization

Source: Researcher 2020

In Figure 7, an overlay visualization is shown, the colour gradation of the node towards yellow indicates a new sub-theme, and the node's colour towards purple indicates the previous analysis subtheme. In this context, there is also a great need for a collaborative research network between countries (America, Europe, and Asia) to guide and expand the dissemination of the sub-title of Paradiplomacy research.

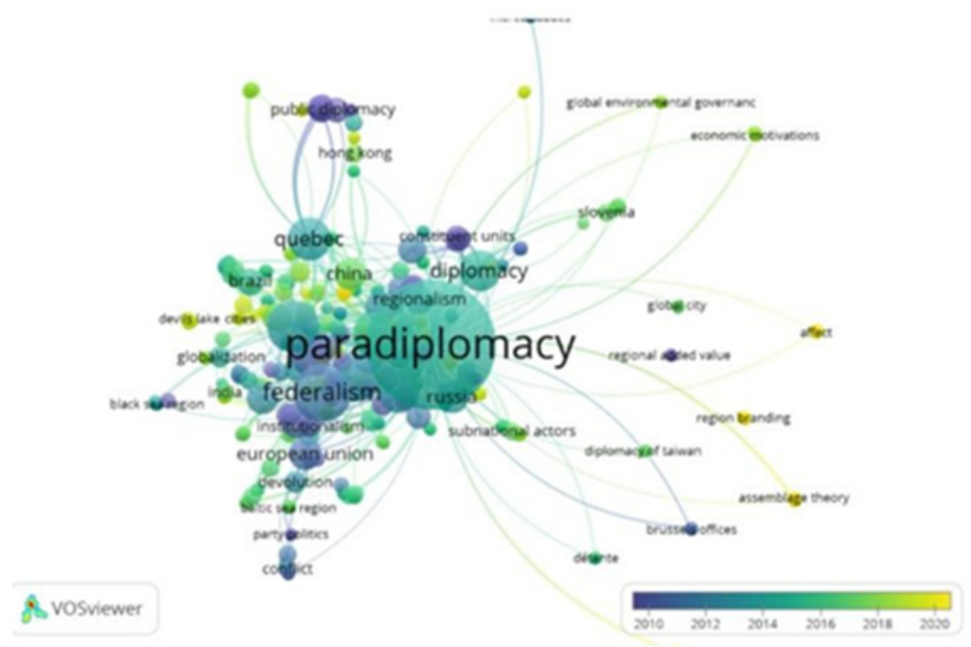

Figure 7: Overlay Visualization

Source: Researcher 2020 
Figure 8 shows the density of visualization, there is a degree of coherence of researchers on many sub-themes of Para-diplomacy, and diplomacy in foreign relations studies is more than $60 \%$. In addition, there are several new sub-themes. This Para-diplomacy research gap takes advantage of a highly dedicated philosophy to the latest studies in international relations, including collaborative analysis, assemble theory, regional branding, and economic motivation.

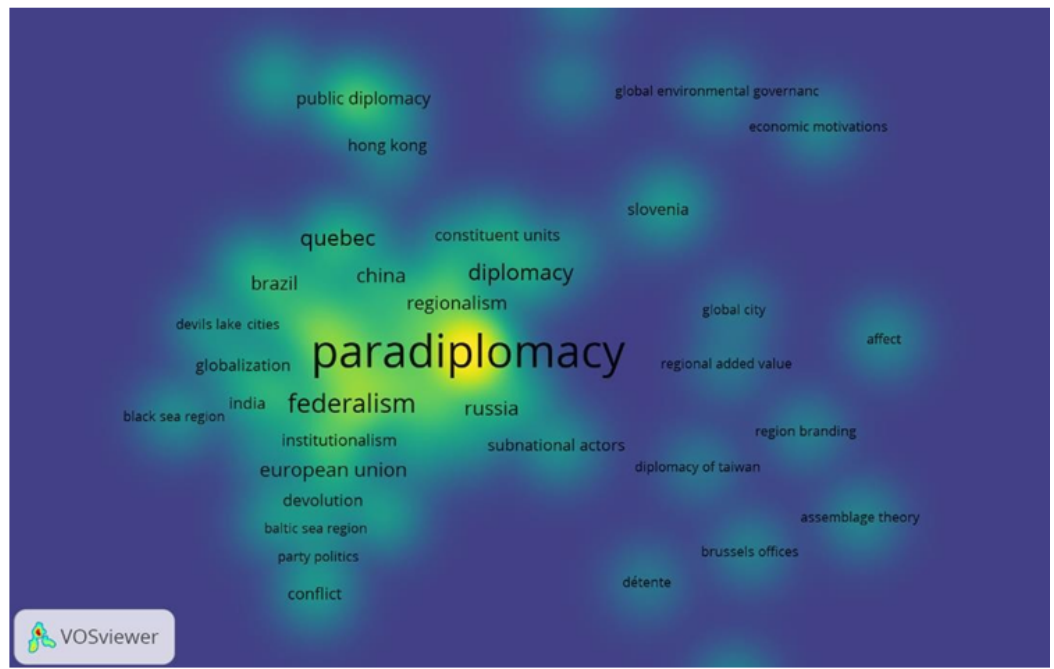

Figure 8: Density Visualization

Source: Researcher 2020

\section{Discussion}

The study of Para-diplomacy in international relations is being introduced as primarily a global activity to achieve foreign policy goals. Many experts have specifically defined Para-diplomacy as a link between public diplomacy in the regions. Although the state's role in diplomacy is still involved, it cannot oversee and encompass all areas of its international activities towards other countries (Paquin et al., 2015). Therefore, this review article contributes to a significant research gap and can provide an analysis of current Para-diplomacy studies based on systematic mapping studies and continued bibliometric analysis VOS Viewer.

Para-diplomacy studies are based on the 12 dimensions of Para-diplomacy, an increasingly essential tool for the horizontal exchange between sub-state governments of public policy. In the light of their capabilities to record and disseminate good practices and experience which can be applied in local environments, even in other countries, municipalities played an essential role in this regards (Nganje, 2014). The twelve dimensions understanding of Para-diplomacy as novelty has been implemented by several developing countries by incorporating their respective strengths, projecting their special interests internationally in a multi-level governance structure that acts as a political intermediary between global and local (Oddone \& Vázquez, 2015) see Figure 9.

Sub-state actors can successfully develop specific Para-diplomacy methods and Dimensions as classified into two categories. The direct methods are carried out by seeking legitimacy and international recognition through the adoption of local laws, signing partnership agreements, establishing representative offices overseas, attracting foreign investment, enhancing the region's international image, working with international organizations and twin cities (Rodrigues \& Mattioli, 2017). Meanwhile, indirect methods affect central legislation, exploitation of national parliaments, 
diplomatic and regional major infrastructure, and the exploitation of international organizations. The combination of direct and indirect strategies has offered the best guarantee of success for Paradiplomacy in the areas bordering developed countries(Zeraoui \& Rey, 2016). Despite the common disputes, state and sub-state governments ultimately tend to consider Para-diplomacy an available resource to increase international activities.

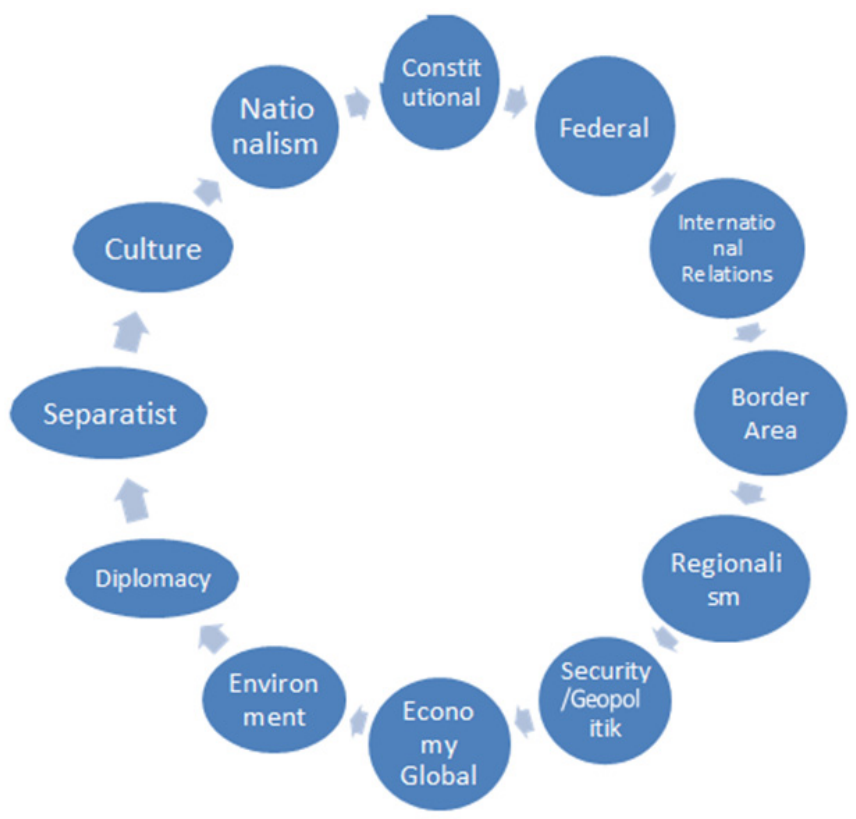

Figure 9: 12 Dimensions of Para-diplomacy

Source: Researcher 2020

\section{Conclusion}

The purpose of this article is to review the state of art or the recent trends and accomplishments of Para-diplomacy in the study of foreign relations. The performance of the SMS indicates several advances in the field of Para-diplomacy that have been studied since 1984 and have improved since 2010. In addition, documents from American countries and newspaper media Q1 from America and Europe have influential regional themes and local diplomacy. Empirically, it is thought that there are still few Asian scholars, but there are a variety of research titles that have recently partnered with American and European research to investigate the topics of Para-diplomacy beyond the framework of diplomacy. Therefore, this review article contributes to a significant research gap and can provide an analysis of current Para-diplomacy studies based on systematic mapping studies and continued bibliometric analysis VOS Viewer.

The Para-diplomacy Research relates to every nation's foreign policy and reflects on the role of foreign parties from sub-state authorities such as Asia. Provinces and municipalities regularly welcome and host foreign delegations, plan festivals, and set up representative offices abroad. In terms of approach, the results of this study are very appropriate for the growth of countries that are already dependent on high technology and modernization. Very few Asian studies have been performed in this field, leading to a substantial research gap. This research has implications theoretically, empirically, and methodologically. Theoretically, Para-diplomacy is a branch of 
diplomacy which is developing recently. Countries in Asia have done very little research, so there is very little theoretical support and research model. This research has a great potential to be discussed and exploited for countries in Asia and become a focal point for the development of topics that previous scholars have identified. Therefore, this article provides a concise overview of the current problem in foreign relations analysis to the dimension of Para-diplomacy scholars.

\section{References}

Aldecoa, F., \& Keating, M. (2013). Paradiplomacy in action: the foreign relations of subnational governments. Routledge.

Kuznetsov, A. S. (2014). Theory and practice of paradiplomacy: subnational governments in international affairs. books.google.com.

https://books.google.com/books?hl=en\&lr=\&id=Zo_ZBAAAQBAJ\&oi=fnd\&pg=PP1\&dq=paradiplomacy\&ots= zxOgTKvAST\&sig=XIYcYFfqLwiAGbl4NUP1QofSR2o

Babar, M. I., Ghazali, M., Ghani, I., Sher, F., Jehanzeb, M., Bhatti, S. N., Jawawi, D. N. A., Abdur Rehman,

A. A., \& Zeshan, F. (2017). Systematic reviews and mapping studies on software requirements : encyclopedia of objectives and issues for newbies. Journal of Software Engineering \& Intelligent Systems, 2(2), 128-155. www.jseis.org

Barlow, D. H., \& Craske, M. G. (2015). Thinking Skills. Mastery of Your Anxiety and Panic: Workbook, August, 97126. https://doi.org/10.1093/med:psych/9780195311358.003.0007

Cornago, N. (1999). Diplomacy and paradiplomacy in the redefinition of international security: Dimensions of conflict and co-operation. Regional and Federal Studies, 9(1), 40-57. https://doi.org/10.108o/13597569908421070

Duchacek, I. D. (1984). The International Dimension of Subnational Self-Government. The Journal of Federalism, 14(4), 5-31. https://doi.org/10.1093/oxfordjournals.pubjof.ao37513

Kaiser, R. (2003). Paradiplomacy and Multi-Level Governance in Europe and North America: Subnational Governments in International Arenas. Participation.

Keating, M. (1999). Regions and international affairs: Motives, opportunities and strategies. Regional and Federal Studies, 9(1), 1-16. https://doi.org/10.1080/13597569908421068

Keohane, R. O., \& Nye, J. S. (1974). Transgovernmental Relations and International Organizations. World Politics, 27(1), 39-62. https://doi.org/10.2307/2009925

Kitchenham, B., Brereton, P., \& Budgen, D. (2012). Mapping study completeness and reliability \pm a case study. Proceedings of the EASE 2012, 126-135.

Lecours, A. (2002). Paradiplomacy: Reflections on the foreign policy and international relations of regions. International Negotiation. https://brill.com/view/journals/iner/7/1/article-p91_8.xml

Lequesne, C., \& Paquin, S. (2017). Federalism, paradiplomacy and foreign policy: A case of mutual neglect. International Negotiation, 22(2), 183-204. https://doi.org/10.1163/15718069-22001133

Liu, T., \& Song, Y. (2020). Chinese Paradiplomacy: A Theoretical Review. SAGE Open, 10(1). https://doi.org/10.1177/2158244019899048

Mansfield, E. D., \& Milner, H. V. (1999). The New Wave of Regionalism. In International Organization (Vol. 53, Issue 3). https://doi.org/10.1162/002081899551002

Munir, F., \& Purnomo, M. (2019). Dimensions of the Para-Diplomacy of Border Areas in International Relations Studies : A Systematic Literature Review. International Journal of Innovations, creativity and Change 10(3), $89-108$.

Nganje, F. (2014). Paradiplomacy and the democratisation of foreign policy in South Africa. South African Journal of International Affairs. https://www.tandfonline.com/doi/abs/10.108o/10220461.2014.895082

Oddone, N., \& Vázquez, H. R. (2015). Cross-Border Paradiplomacy in L atin A merica. Latin American Policy, 6(1), 110-123. https://onlinelibrary.wiley.com/doi/abs/10.1111/lamp.12059

Paquin, S., Kravagna, M., \& Reuchamps, M. (2015). Paradiplomacy and International Treaty Making: Quebec and Wallonia Compared. Federations: A Comparative Study of Quebec

Petersen, K., Feldt, R., Mujtaba, S., \& Mattsson, M. (2008). Systematic Mapping Studies in Software Engineering (Vol. 17). https://doi.org/10.1142/So218194007003112

Purnomo, M. (2015). Systematic Mapping of Urban Entrepreneurship. Hasil - Hasil Penelitian Dan Pengabdian LPPM Universitas Muhammadiyah Purwokerto Sabtu, 26 September 2015, September, 101-109.

Rodrigues, G. M. A., \& Mattioli, T. (2017). Paradiplomacy, security policies and city networks: the case of the Mercocities Citizen Security Thematic Unit. In Contexto Internacional. SciELO Brasil. http://www.scielo.br/scielo.php?pid=So102-85292017000300569\&script=sci_arttext 
Slaughter, A. M. (2004). Disaggregated Sovereignty: Towards the Public Accountability of Global Government Networks. Government and Opposition, 39(2), 28-37. https://doi.org/10.1111/j.1477-7053.2004.00119.X

Tewari, F. (2017). Paradiplomacy in India: evolution and operationalisation. In ORF India. cf.orfonline.org. http://cf.orfonline.org/wp-content/uploads/2017/o8/ORF_OccasionalPaper_119_Paradiplomacy.pdf

Wang, W., Laengle, S., Merigó, J. M., Yu, D., Herrera-Viedma, E., Cobo, M. J., \& Bouchon-Meunier, B. (2018). A Bibliometric Analysis of the First Twenty-Five Years of the International Journal of Uncertainty, Fuzziness and Knowledge-Based Systems. International Journal of Uncertainty, Fuzziness and Knowlege-Based Systems, 26(2), 169-193. https://doi.org/10.1142/So218488518500095

Zeraoui, Z., \& Rey, F. (2016). The paradiplomacy of the cities. A strategy of urban development . Reforma $y$ Democracia, 2016-June(65), 225-242. https://www.scopus.com/inward/record.uri?eid=2-s2.085010867754\&partnerID=4o\&md $5=$ c6a4e34eeca814o6defidob5d67a3710 